\title{
Perhitungan "Rongga Kanal” pada Komunikasi Data
}

\author{
Sigit Haryadi \\ Institut Teknologi Bandung
}

\section{Paper DOI10.17605/OSF.IO/Y3WCG}

Haryadi, S. (2018, February 24). Perhitungan “Rongga Kanal” pada Komunikasi Data.

Retrieved from osf.io/preprints/inarxiv/y3wcg

\section{Ringkasan}

“Rongga Kanal” adalah ukuran kekosongan dari suatu kanal komunikasi yang berpeluang untuk dimanfaatkan secara positif atau negative tergantung penggunanya, yang disebabkan adanya distribusi kemunculan symbol yang tidak merata pada suatu transmisi data. Lebih jauh, pengukuran "Rongga Kanal" dilakukan menggunakan rumus "Entropi Informasi" yang dibuat oleh Claude Shannon pada tahun 1948, yang diadaptasi oleh rumus "Indeks Haryadi” yang dibuat oleh Sigit Haryadi pada tahun 2016.

\section{Rumus "Rongga Kanal"}

\subsection{Rumus Generik}

$$
\text { Rongga Kanal (bit) } \left.=\log _{2}\left[n *\left\{\sum_{i=1}^{n} p_{i}^{2}+\sum_{i=1}^{n} \sum_{j=1}^{n}\left(p_{i}-p_{j}\right)^{2}\right\}\right] ; i>j\right)
$$

Dimana: $\mathrm{n}=$ ukuran atau banyaknya symbol dan pi = peluang munculnya symbol ke-i

\subsection{Contoh - contoh rumus}

$$
\begin{gathered}
\text { Rongga Kanal (bit) }{ }_{n=2}=\log _{2}\left[2 *\left\{p_{1}^{2}+p_{2}^{2}+\left(p_{1}-p_{2}\right)^{2}\right\}\right] \\
\text { Rongga Kanal (bit) })_{n=3}=\log _{2}\left[3 *\left\{p_{1}^{2}+p_{2}^{2}+p_{3}^{2}+\left(p_{1}-p_{2}\right)^{2}+\left(p_{1}-p_{3}\right)^{2}+\left(p_{2}-p_{3}\right)^{2}\right\}\right] \\
\text { Rongga Kanal (bit })_{n=4}=\log _{2}\left[4 *\left\{p_{1}^{2}+p_{2}^{2}+p_{3}^{2}+p_{4}^{2}+\left(p_{1}-p_{2}\right)^{2}+\left(p_{1}-p_{3}\right)^{2}+\left(p_{1}-p_{4}\right)^{2}+\left(p_{2}-p_{3}\right)^{2}+\left(p_{2}-p_{4}\right)^{2}+\left(p_{3}-p_{4}\right)^{2}\right\}\right]
\end{gathered}
$$

\subsection{Tingkat "Kekosongan" pada Kanal Komunikasi}

Hipotesis dari tingkat "kekosongan" pada suatu kanal komunikasi adalah sebagai berikut:

a) "Rongga Kanal" kurang dari 0,415 bit adalah bersesuaian dengan tingkat "kekosongan" yang kecil dari kanal komunikasi.

b) "Rongga Kanal" antara 0,415 bit sampai dengan 1 bit adalah bersesuaian dengan tingkat "kekosongan" yang menengah dari kanal komunikasi.

c) "Rongga Kanal" lebih dari 1 bit adalah bersesuaian dengan tingkat "kekosongan" yang besar dari kanal komunikasi. 


\section{Kalkulator Internet}

\subsection{Website Kalkulator}

Untuk memudahkan pengguna umum, dibuatkan suatu kalkulator internet yang terkait dengan makalah ini di http://sigitharyadi.net/id/multidicipline/channel-cavity/

\subsection{Prosedur Penggunaan Kalkulator}

I. Isilah banyaknya symbol yang muncul pada transmisi data, boleh diamati seluruh symbol, bisa juga hanya diamati sebagian yang dianggap penting.

a. Sebagai contoh, anda sedang peduli pada peluang kemunculan symbol pada alphabet Latin, tanpa peduli dituliskan menggunakan huruf besar atau huruf kecil, dan tidak peduli pada tanda baca dan symbol numeric, maka dalam hal ini, banyaknya symbol adalah 26 .

b. Contoh lain, anda sedang peduli pada peluang kemunculan empat bit berturutan, 0000, 0001, 0010, $0011 \ldots 1111$, maka dalam hal ini banyaknya symbol yang anda masukan adalah 16 .

II. Isikan distribusi kemunculan dari setiap symbol, pastikan anda TIDAK memasukkan symbol yang tidak pernah muncul.

III. Tekan CALCULATE

\section{Catatan}

Untuk lebih memperdalam mengenai indeks Haryadi yang menjadi roh dari rumus yang dipromosikan pada makalah ini, silahkan membaca pustaka berikut ini.

\section{References}

[1] Sigit Haryadi. (2017). Haryadi Index and Its Applications in Science of Law, Sociology, Economics, Statistics, and Telecommunications. Penerbit Elex Media Komputindo. Jakarta. ISBN 978-602-02-9895-5.

[2] Sigit Haryadi. (2017). Indeks Haryadi dan Penerapan di Ilmu Hukum, Sosiologi, Ekonomi, Statistik, dan Telekomunikasi. Penerbit Elex Media Komputindo, Jakarta. ISBN 978-602-029896-2

[3] Haryadi, S. (2018, February 22). Equality Correlation Calculation. Research gate. DOI 10.13140/RG.2.2.22068.76168

[4] Haryadi, S. (2018, February 22). Kalkulator Untuk Menghitung Korelasi Kesetaraan. Retrieved from osf.io/preprints/inarxiv/7r9jy

[5] Haryadi, S. (2018, February 17). Calculation the Competition Levels between Students in Class and the Relation to the Teacher or Lecture Fairness in Teaching. Researchgate. DOI10.13140/RG.2.2.30359.06569

[6] Haryadi, S. (2018, February 17). Perhitungan Tingkat Kompetisi antar Murid atau Mahasiswa di Kelas dan Kaitannya Dengan Keadilan Guru atau Dosen Dalam Mengajar. Retrieved from osf.io/a894w

[7] Sigit Haryadi. (2017). the Equality Correlation Method. Researchgate. DOI10.13140/RG.2.2.10443.80169. 
[8] Sigit Haryadi. (2017). Calculation of the Mobile Communication Competition using Haryadi Index. DOI10.13140/RG.2.2.15634.25280

[9] Haryadi, S. (2018, February 1). Kalkulator Untuk Mengukur Tingkat Kompetisi di suatu Industri, dengan menggunakan rumus Indeks Haryadi. Retrieved from osf.io/fy7zu

[10]Haryadi, S. (2018, February 7). Statistik Terapan: Pengujian Regulasi \& Kebijakan Telekomunikasi. Retrieved from osf.io/3pkfw

[11]Sigit Haryadi. (2018, February). Applied Statistics for Assessment of the Regulation and Policy: case study in Telecommunication Industry. DOI10.13140/RG.2.2.15774.02884

[12] Haryadi, S. (2018, February 1). KALKULATOR untuk membuat Regresi Linier Tanpa Intersep. Retrieved from osf.io/emvs7

[13]Sigit Haryadi. (2017, December). Calculator for non-intercept linear regression. Researchgate. DOI10.13140/RG.2.2.15761.94562.

[14]Sigit Haryadi. (2017, December). Calculator for Measurement the Competition Index \& Level. Researchgate. DOI10.13140/RG.2.2.23626.26568

[15]Sigit Haryadi. (2017). The. Fairness over Inequality Index: Unfairness is Disaster - a notebook of Sigit Haryadi. Researchgate. DOI10.13140/RG.2.2.34379.49449.

[16]Haryadi, S. (2017, November). Probabilitas Statistik Untuk Insinyur. Researchgate. DOI10.13140/RG.2.2.14304.58885

[17]Sigit Haryadi. (2017). Harmony in Gradation and its prospects as the Formula of Everything, First edition of posts: December 31, 2017. Researchgate. DOI10.13140/RG.2.2.19309.08169

[18]Nie Levin Kusuma Adiatma; Sigit Haryadi. (2017, October). Comparison of the Haryadi Index with Existing Method in Competition, Equality, Fairness, and Correlation Level Calculation Case Study: Telecommunication Industry. The 11th International Conference on Telecommunication Systems, Services, and Applications, at Lombok, Indonesia.

[19]Sigit Haryadi; Dyah Rakhma Ariyanti. (October 2017). The Fairness of Resource Allocation and Its Impact on 5G Ultra-Dense Cellular Network Performance. The 11th International Conference on Telecommunication Systems, Services, and Applications, at Lombok, Indonesia.

[20]Dyah Rakhma Ariyanti; Sigit Haryadi. (October 2017). Analysis of Harmony in Gradation Index on 5G Cellular Network Quantitative Analysis. The 11th International Conference on Telecommunication Systems, Services, and Applications, at Lombok, Indonesia.

[21]Sigit Haryadi. (2017). the Non-Intercept Linear Regression Method. Researchgate. DOI10.13140/RG.2.2.18721.71522

[22]Sigit Haryadi. (2017, January). Calculation of the Income Equality Levels between Regions using the Haryadi Index. Researchgate. DOI10.13140/RG.2.2.36605.77282

[23]Sigit Haryadi. (2016). Haryadi Index for Competition, Equality and Correlation Evaluation. Penerbit Lantip Safari Media, Bandung, Indonesia. ISBN 978-602-73231-3-2

[24]Sigit Haryadi. (2016). Haryadi Index untuk Evaluasi Kompetisi, Kesetaraan dan Korelasi. Penerbit Lantip Safari Media, Bandung, Indonesia. ISBN 978-602-73231-3-1

[25]Haryadi, S. (2018, February 1). Indeks Haryadi dan Prospeknya Untuk Menjadi Suatu "Formula of Everything (versi 31 Desember 2017). Retrieved from osf.io/zex45 